\title{
Traditional conflict management initiatives in Africa: Wellness models for southern Africa and the Zimbabwean crisis
}

\author{
Maxwell C.C. Musingafi ${ }^{1 *} \quad$ Racheal Mafumbate $^{2} \quad$ Thandi F. Khumalo ${ }^{3}$ \\ 1.Zimbabwe Open University, Department of Development Studies, Faculty of Applied Social Sciences \\ 2.University of Eswatini, Department of Educational Foundations and Management, Faculty of Educatio \\ 3.University of Eswatini, Department of Sociology and Social Work, Faculty of Social Sciences
}

\begin{abstract}
In this paper we acknowledge that people are inherently different, and conflict simply happens when those differences come to light. We argue that equipped with an appropriate conflict management process, people can explore and understand those differences, and use them to interact in a more positive, productive way. This paper is anchored on the argument that resources are scarce and thus people are bound to clash over their distribution. We view conflict as unavoidable. We are guided by African approaches to conflict management in which emphasis is on wellness, sacredness of human life, cohabitation and working together for progress and development. We argue that experience in the modern world has taught us that our understanding of conflict has a critical bearing on our response to its emergence. If conflict is considered to be inherently destructive, then our efforts are bound to be directed towards suppressing it. If we view conflict as normal and inescapable, then the challenge lies in managing it constructively. We argue that the major point about conflict management in Africa is the emphasis on resolving of conflicts amicably through elders, traditional leaders, healing and reconciliation rituals.
\end{abstract}

Keywords: Conflict, management, ubuntu, wellness, initiatives, traditional, Africa.

DOI: $10.7176 / \mathrm{JCSD} / 47-07$

Publication date: April $30^{\text {th }} 2019$

\section{Orientation and background information}

Since turn of the Millennium Zimbabwe has been in what has become one of its most destructive political conflict and economic crisis. We write this paper to remind the country of the rich African philosophies in dealing with conflict.

Musingafi, Dumbu, Mupa, Chiome and Chikukwa (2011) observe that people often assume that conflict is always negative. They argue that this is not true for people are inherently different, and conflict simply happens when those differences come to light. Whether at home with our families, at work with colleagues or in negotiations between governments, conflict pervades our relationships. Thus, conflict is an inevitable and necessary feature of our lives. The challenge facing us is not the elimination of conflict, but rather, how to effectively address conflict when it arises.

According to Miller and King (2005) the word conflict is derived from the Latin word for 'to clash or engage in a fight' and thus it can be seen as a confrontation between one or more parties aspiring towards incompatible or competitive means or ends. Conflict is contest between people with opposing needs, ideas, beliefs, values, or goals (Musingafi, et al, 2011). It is present when parties perceive that their interests are incompatible, express hostile attitudes or pursue their interests through actions that may damage the other parties. Thus, conflict is inevitable, may escalate and lead to nonproductive results, or can be beneficially resolved and lead to quality final products. Although very few people go looking for conflict, more often than not, conflict results because of miscommunication between people with regard to their needs, ideas, beliefs, goals, or values (Musingafi, et al, 2011).

When one speaks of a conflict, it is normally taken to mean chaos, wars or mutual suspicion or strained relations, competition, hatred and many other associated ills. Figure 1 shows that it is incorrect to always regard conflict as something very destructive which deserves avoidance or denouncing. Depending on how we respond to conflict, it can be a source of violence and misunderstandings or a source of transformation. Once mishandled, it can result into a discord, chaos or even war. Equally so, if properly handled conflict can be a source of development. 
Figure 1. The nature of conflict transformation (Source: National Unity and Reconciliation Commission. 2006)

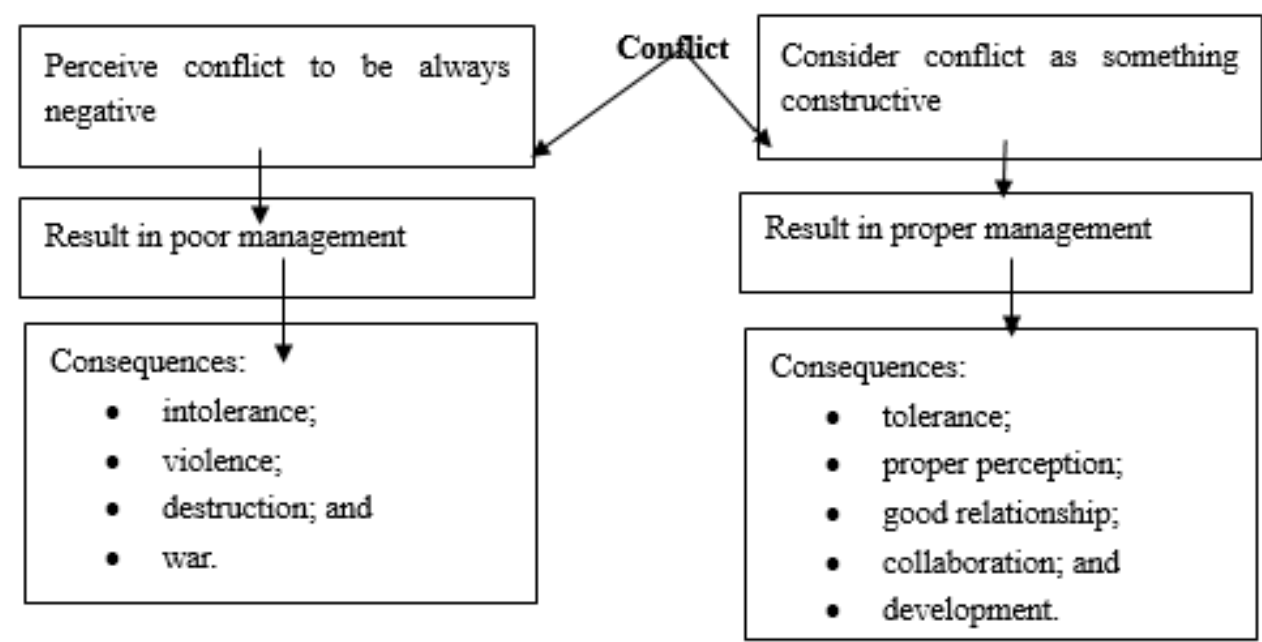

Distinction is made between 'negative peace' and 'positive peace' (Galtung, 1996). Negative peace refers to the absence of violence. When, for example, a ceasefire is enacted, a negative peace will ensue. It is negative because something undesirable stopped happening. In most negative situations people are peaceful not because they want to be peaceful but because they are afraid of security forces. They only need a small trigger to become violent. Examples are authoritarian regimes in post-colonial Africa in which people seem peaceful yet deep down their hearts they are boiling up. In Rhodesia Smith claimed that the Blacks were happy with their situation and therefore peaceful. Nevertheless, history has shown that they were discontented with the colonial regime. Positive peace is filled with positive content such as the restoration of relationships, the creation of social systems that serve the needs of the whole population and the constructive resolution of dysfunctional conflict.

It is however important to note that peace does not mean the total absence of any conflict. It means the absence of violence in all its forms and the unfolding of conflict in a constructive way. Peace therefore exists where people are interacting non-violently and are managing their conflict positively - with respectful attention to the legitimate needs and interests of all concerned.

Reconciliation becomes necessary when negative or dysfunctional conflict has occurred and relationships have been damaged. Reconciliation is especially important in situations of high interdependence where a complete physical or emotional barrier between parties in a conflict cannot be maintained. Reconciliation therefore refers to the restoration of relationships to a level where co-operation and trust become possible again. Lederach

(1995) stated that reconciliation deals with three specific paradoxes:

- promotes an encounter between the open expression of the painful past and the search for the articulation of a long-term, interdependent future;

- $\quad$ provides a place for truth and mercy to meet; where concern for exposing what happened and letting go in favour of a renewed relationship are validated and embraced; and

- recognises the need to give time and place to justice and peace, where redressing the wrong is held together with the vision of a common, connected future.

The Ugandan proverb 'no monkey destroys his forest' hints at the value of interpersonal relationships. The gist of the proverb is that one should maintain relationships and take care of friendships because everyone needs other people. To maintain friendships is to address interpersonal conflicts in a way that leads to further interaction and restores errant individuals to the community (Jabs, 2014).

\section{African traditional conflict management and resolution mechanisms}

African traditional conflict management mechanisms have been there before and during colonialism as well as in the contemporary Africa (post-independence era). According to Ayindo and Jenner (2008), laws and conflict management techniques in African societies are closely related to the whole system of morality and ethics of African religion. "It is hard to separate "law" in African tradition from custom, taboo, divination, mediumship, ordeals and the expectations of sharing, harmony, play and good company in general. It is also difficult to separate resolution of conflict from the structures of family, lineage, clan and the various sodalities' (Ayindo and Jenner, 2008: 5). Thus, the African legal system and moral system are inseparable. Punishment or coercion generally takes the form of moral pressure. Throughout the court hearing, the judges try to prevent the breaking of relationships, and to make it possible for the parties to live together amicably in the future. Judgements are 
meant to be both conciliatory and therapeutic. They reeducate the parties and the entire community through a type of social learning brought about in a specially structured interpersonal setting. What is central in the judicial process is the act of listening by those whose task is to make the judgement between the litigant and plaintiff. This is usually done at great length, sometimes with details seemingly irrelevant to the case (Ayindo and Jenner, 2008). The shedding of blood, even enemy blood, is always inauspicious, and is invariably followed by elaborate rituals of purification.

What the African worldview emphasizes, therefore, are relationships. Through the act of creation, God is related in an unbreakable way to the entire universe. At the centre of the universe is humanity, but it too is intrinsically and inseparably connected to all living and non-living creation by means of each creature's life force. Although God, spiritual beings, ancestors, humanity, living things and non-living things enjoy life forces with greater and lesser powers, all forces are intertwined. Their purpose ultimately is humanity; they can act either to increase or suppress the vital force of an individual person or for a community. Ayindo and Jenner (2008) observe that:

- a conflict resolution/peace process is an opportunity for the education of the whole community;

- reconciliation is not just about humans; conflict causes disequilibria within other realms of existence, hence the need for rituals of resolution;

- $\quad$ in the process of responding to conflict, we must still respect humans by saving their face and avoid embarrassing and/or shaming people;

- the language of conflict resolution should encourage resolution by avoiding embarrassment and breaking barriers;

- face saving creates the space for self-examination and invites all the parties in conflict to listen to each other; and

- the process of resolving conflicts should be inclusive; the language was designed to accommodate different levels of meaning so that everyone was included.

\subsection{Traditional conflict resolution methods in southern Africa Ubuntu}

As already observed above, in southern Africa (South Africa, Zimbabwe, Botswana, Swaziland, Lesotho, Mozambique, Zambia, Namibia, among others) emphasis is on cohabitation and sacredness of human life. In most of these countries, cohabitation, relationships and wellness are put ahead of everything else. Mechanisms to ensure peaceful coexistence include tribal intermarriages (in Swaziland the King marries from all groupings in the country); offering hospitality to strangers (in Namibia they even surrender their wives to respectable male visitors for the time they are visiting); and initiation and many other get together ceremonies. In this subsection we just look at the $u b u n t u$ and dare traditions

\subsubsection{The ubuntu / unhu tradition}

Masina (2000: 170) states that ubuntu literally means "collective personhood" or the "art or virtue of being human". Basic characteristics of ubuntu include "caring, compassion, unity, tolerance, respect, closeness, generosity, genuineness, empathy, consultation, compromise, and hospitality". Ubuntu emphasizes working together to solve problems, so members of the community are responsive to the idea of cooperating with extended family, elders, chiefs and headmen to work through concerns in a way that results in the reconciliation of all members of the community (Masina, 2000 cited in Jabs, 2014).

Further Jabs (2014) narrates that as a way of life, ubuntu, functions both as a conflict prevention mechanism and a conflict resolution process. Breaking ubuntu incurs sanctions that vary from fines to isolation. These penalties are rarely necessary, however, because family and social bonds are taught and communicated from the time a child is born and, as a result, ubuntu is rarely breached. When conflict does occur, it is more quickly resolved because of the ubuntu belief that one can be a person only through others. This idea is expressed succinctly in the Nguni proverb "I am because we are" (Masina, 2000: 170). Ubuntu emphasizes working together to solve problems, so members of the community are responsive to the idea of cooperating with extended family, elders, chiefs and headmen to work through concerns in a way that results in the reconciliation of all members of the community (Jabs, 2014).

\subsubsection{The dare tradition}

Dare is a local court in Zimbabwe, which comprises the village head and a council of advisors and community members. It is a conflict resolution institution found among the Shona people. Criminal and civil cases are tried in the presence of local community members and the village head, in consultation with the council advisors, gives a ruling. According to the Zimbabwe constitution, a dare can refer a case to the modern court if the case contents prove to be beyond its jurisdiction.

\subsection{Traditional conflict resolution methods in Rwanda}

According to Anastase (2015) in sub-Saharan Africa, Rwanda offers extensive lessons in traditional mechanisms for conflict management. Some of the traditional conflict resolution mechanisms found in Rwanda include 
Gacaca courts, Ingando and the Abunzi mediation traditions.

\subsubsection{The Agacaca method of conflict resolution in Rwanda}

According to Anastase (2015), although the Hutu, Tutsi, and Twa entities existed prior to the eruption of mass violence in Rwanda in the 1950s, they were not primary identities, nor were they genetically concrete identities as was advocated by the colonial Hamitic theory. The reality is that prior to the genocide and the 1959 social revolution (which reflected indoctrination of the Hamitic hypothesis by Rwandans), the Rwandan identity reference was the clan first (ibid). Every Rwandan belonged to any of 18 common clans in the Rwandan genealogy and none of them was exclusively Hutu or Tutsi. Then, depending on their socio-economic status or their proximity to the monarchy and ruling clans, they could be identified as Hutu, Tutsi, or Twa. Nevertheless, Hutu and Tutsi have now become genocide identities (ibid).

Before the arrival of Europeans, Gacaca was the court of first instance of the local area (Mutisi, 2011). Gacaca was presided over by persons of integrity who used to congregate and settled any disputes or conflicts that came up in the society (Ayindo and Jenner, 2008). The Gacaca courts had competence to settle everyday conflicts of civil nature like divorce, land, libel or defamation and other kinds of unbecoming behaviour. During the colonial period, Gacaca courts continued existing. However, greater power was accorded to ordinary courts of written laws.

A 1996 law and the 2003 constitution called on Gacaca courts to try those accused of genocide. Gacaca literally means "a resting and relaxing green lawn in the Rwandan homestead" where family members or neighbours met to exchange views on issues directly affecting them or their community (Karbo and Mutisi, 2008). Gacaca were traditional councils and tribunals made up of men or elders to resolve conflict, administrate justice, promote reconciliation and consolidate social cohesion. Being communal and participatory, the Gacaca derived its impetus and legitimacy from the unity of Rwandans and cemented the same unity and social cohesion. Members of Gacaca were called impfura, meaning a person of moral integrity, positive role-model and adhering to socio-cultural standards and values (Anastase, 2015).

Today's Gacaca, while inspired from the traditional one, are in practice very different. In the past, Gacaca settled communal conflicts in an environment of social cohesion, while today Rwandan society is deeply divided (Anastase, 2015). It deals with genocide crimes, while the traditional Gacaca was related to communal issues but not mass murder. It is also important to note that the traditional impfura were only men of a certain age; today, women and youth of 21 years and older have been elected to serve as Gacaca judges (ibid).

The Gacaca's overall strategy can be summarized as follows: eliciting the truth from stakeholders; administering justice and challenging impunity; establishing collective ownership of the tragedy; and finding some measure of reconciliation through mediation. Truth, justice and reconciliation are the very facets of that process. The challenge lies in that justice, peace and reconciliation are not always compatible, but they are all needed in post-conflict situations. The ultimate goal of Gacaca is reconciliation (Karbo and Mutisi, 2008).

For Rwanda, this is still a process to build and a battle to win. President Paul Kagame, during his address in commemoration of the 10th anniversary of the genocide in 2004, noted that Gacaca "is designed to balance the needs of justice and those of reconciliation, so that through the process of catharsis, a healing process can be cemented through reconciliation." Gacaca is the forefront of this struggle and its outcome will impact national cohesion and reconstruction (Anastase, 2015).

\subsubsection{The Ingando tradition for social cohesion in Rwanda}

According to Anastase (2015), Ingando refers to halting normal activities and reflecting in order to find solutions to big challenges affecting one's community or the nation. Ingando were first developed by the military in ancient Rwanda. Through Ingando, the King of Rwanda prepared and mobilized the population whenever the country was facing disaster. Ingando lost its relevance in the colonial era, together with other monarchic institutions and practices cementing social cohesion.

After the 1994 genocide, the Rwandan Patriotic Army (RPA) revived Ingando, which were used to integrate the ex-Armed Forces of Rwanda (FAR) into the new army. When the National Unity and Reconciliation Commission was established in 1999, it formally developed Ingando as a tool for peace building within communities. Primarily, Ingando focused on reintegration of combatants from the DRC and insurgency battles in the North. The programme later expanded to students, local leaders and other social groups. Today, solidarity camps are conducted throughout the country. Their focus is on improving governance and development, and establishing the history of Rwanda and genocide related issues. Ingando helps to consolidate social cohesion and strengthen national unity. It stands as a confidence building tool and a forum for political and civic education. It is a powerful transformational tool for a divided society which went through massive criminalization of the people (Anastase, 2015).

\subsubsection{The Abunzi mediation in Rwanda}

The Abunzi mediation is part of the Rwandan justice system, whose restorative approach helps people to address their conflicts without resorting to litigation and other retributive approaches. Literally translated, the word abunzi means 'those who reconcile' (Boege, 2006). The Abunzi are local mediators in Rwanda, who are 
mandated by the state as the conciliatory approach to resolve disputes, ensuring mutually acceptable solutions to the conflict (Mutisi, 2011). The Abunzi mediators are chosen on the basis of their integrity, and they handle local cases of civil and criminal nature (Boege, 2006). The abunzi system was popularised in the post-2000 era by the Rwandan government as a way of decentralising justice, making it affordable and accessible (Mutisi, 2011). The resuscitation of the abunzi is part of the Rwandan government's repertoire of initiatives designed to make justice and governance available to citizens at every level. The abunzi exist alongside other decentralised forms of governance in Rwanda, including the Gacaca courts.

Before seeking justice in local courts, mediation by the Abunzi is obligatory for local level disputes, criminal cases and civil cases, whose property value is below 3 million Rwandese francs. (Boege, 2006). Like their counterpart institution of Gacaca courts, which has tried more than 1 million cases of genocide, the Abunzi system is inspired by Rwandan traditional dispute resolution systems that encourage local capacity in the resolution of conflicts (Mutisi, 2011). In a way, Abunzi can be seen as a hybrid between state-sponsored justice and traditional methods of conflict resolution, as it helps to address the challenges of an overburdened modern court system (ibid).

Abunzi mediation sessions are open to family members of the disputants, as well as members of the public. During Abunzi sessions and meetings, there is often a great deal of evocation of the notion of 'oneness' or the concept of abanyarwanda (Rwandan-ness), as opposed to being Hutu, Tutsi or Twa. When compared with the retributive system of the modern courts, the Abunzi mediation processes tend to reflect values and principles of decentralisation of power, communal participation and consensus-based decision-making (Mutisi, 2011).

\subsection{Traditional conflict resolution methods in Kenya ${ }^{l}$}

In pre-colonial Kenyan communities conflict could be resolved through use of the council of elders composed of elderly men and women acting as third parties. Moreover, disputants could be amicably reconciled by the elders and close family relations and advised on the need to co-exist harmoniously. Thus, traditional conflict resolution mechanisms were geared towards fostering peaceful co-existence among Kenyans. The importance of traditional conflict resolution mechanisms in Kenya has been given recognition by Article 159 of the Constitution of Kenya, 2010.

\subsubsection{Conflict resolution through the council of elders}

The council of elders is a common mechanism that has been in resolving conflicts in many areas in Kenya. It is ordinarily the first point of call when any dispute arises in a community.

Among the Pokot and the Marakwet the council of elders is referred to as kokwo and is the highest institution of conflict management and socio-political organisation. The council of elders among the Gikuyu is referred to as the Kiama. It is composed of respected, wise old men who are knowledgeable in the affairs and history of the community.

Traditionally, the consensus approach is used where resolutions were attained on the basis of consensus rather than on winner-takes-all approach. Consensual outcomes are highly regarded as they create confidence as parties have autonomy over the process. Thus, the decision of the elders is effective, durable and long lasting. An agreement reached through consensus is communicated to the whole community and affirmed as a social contract in a ritual way. This is done to pass the news of the satisfactory conclusion of the conflict resolution process. In terms of implementing the agreement the parties and the entire community follow up to confirm compliance with the agreement.

In most cases, the council of lders in the disputing parties meet separately to discuss the possibility of agreeing to meet the opponents at a joint forum. A peace emissary usually adorned in a manner that portrays him to the enemy that he is bringing a message of reconciliation. Conflicting parties are forbidden from attacking or killing such an emissary as this is perceived as taboo.

Once both parties agree on the date and venue, which is often under a tree for the resolution or reconciliation meeting, elders of the involved group come together for a dialogue. Usually such encounters result in a peace deal and agreements for coexistence. While coming to such negotiations, both groups bring food and drinks. A white and blameless animal is then slaughtered by the offending party, to be shared across the divide. Symbolically there are traditional objects among communities usually used during such peace negotiations.

\subsubsection{Conflict resolution through the Wajir peace initiative}

The Wajir peace initiative is a woman driven initiative aimed at resolving inter-communal conflicts in northern Kenya. Inter-communal conflicts pose a problem for the stability among pastoralist societies, especially in Kenya, and it was these specifically that fostered the development of solutions in order to pacify the communities of arid lands. In order to bring an end to ongoing conflicts in the 1990s between arid lands ethnic groups local actors started ad hoc peace initiatives. The most well-known is the Wajir peace and development committee (WPDC). During years of intense conflict in Wajir district, a small group of educated Somali women

\footnotetext{
${ }^{1}$ All the information in this section has been adapted from UPEACE AFRICA PROGRAMME, 2013
} 
began to meet with local market women to discuss conflict prevention. These women formed Wajir Women for Peace, which later joined with a group of other educated Somalis to form the Wajir Peace Group. This group first approached elders in warring communities, gradually expanding their peace building and mediation efforts to youths, sheiks, business leaders, civil servants and the district commissioner.

Through this initiative committees are formed to facilitate meetings, in which the conflicting parties can negotiate common ground rules that comply with each of their own paradigms. The Garissa Declaration is one of the outcomes of these initiatives. In April 2001, the government's security committees and community elders of the districts of Isiolo, Marsabit, Moyale, Wajir and Garissa met with stakeholders of the districts and provinces with the purpose of negotiating solutions for the frequent conflicts in the area. Jointly they discussed and outlined the modes of a peace agreement, which resulted in a document called the Modogashe Declaration. The Declaration sets out the overall issues that threaten to erupt in conflict, such as cattle rustling, disputed use of pasture and water sources and trafficking of illegal firearms.

Peace committees have been useful in inter-ethnic or cross-district boundaries. They allow for peaceful interaction between representatives of different groups, even across district boundaries. In the case of cattle theft, for example, the committees send response teams to pursue the footprints of the cattle. They follow the tracks and report to the police, district officers and chiefs. If the cattle have been herded across district boundaries, they contact the peace committee of the neighbouring district and seek their cooperation. Once the location of the stolen cattle is identified, they request the return of the cattle from the committee in the other district. In case the cattle are not returned, the peace committees from both sides mediate and negotiate the compensation for the victim's group.

\subsection{Traditional conflict resolution methods in Ethiopia ${ }^{1}$ \\ 2.4.1 The Gaada system}

The Gaada system is a traditional system among the Oromia people in Ethiopia to guide the social, economic, political and religious life of the people especially in managing resources. Gaada is a system of social organisation based on age grade classes of the male population that succeed each other every 8 years in assuming economic, social, political and military responsibilities. It divides the men in the community into 5 main age groups in which each group has a role to play in maintaining the flocks, the water, the land and the peace.

Those over the age of 48 are considered YUBBA. They are considered to be old and wise with the responsibility of taking on an advisory role. Any boy under the age of 9 has only a symbolic role as a mediator between God and human. Then there is the ABBAA GADAA who is the leader of the Gaada. He is called to pronounce judgement in conflict between communities. The conflicts usually resolved under this system relate to conflicts over access and use of water resources.

\subsubsection{The Michu and Luba Basa Systems in Western Ethiopia}

The Gumuz people predominate in the Metekkel area of western Ethiopia next to the Sudan border. In this isolated part of the country, neighbouring Amhara and Omoro people have moved into Metekkel over the years resulting in disputes over land and resources. As a result a mechanism known as michu or friendship developed to resolve ethnic conflict and to create an environment of tolerance and mutual coexistence. The conflicting parties invoke michu when serious problems arise. Michu establishes the free movement of people and is used by all the inhabitants of the region. Ethnic groups living in Metekkel prefer to entrust their differences to michu mechanism than to a government court. To this day michu plays an important role in preventing conflicts in the region.

The michu conflict resolution mechanism employs the use of rituals in the process of conflict resolution. At the end of the ceremonies, a bull or goats and fowls are slaughtered, followed by traditional merry making. The Gumuz usually prefer a fowl, and if the parties involved slaughter a fowl, it is considered a sign of friendship. At the end songs, traditional merry making, hugging and invocation of spirits continue. The ceremony is concluded after the elders and clan chiefs shake hands as a sign of peace and future cooperation.

Neighbouring Oromo developed a similar concept known as luba basa meaning to set free. As the Oromo migrated into territory occupied by other ethnic groups, they created luba basa as a traditional system to reduce conflict. The Oromo considered non-Oromo groups castes and treated them as inferiors, sometimes harshly, until they are assimilated through the luba basa institution.

\subsection{Traditional conflict resolution in Burundi: The Bashingantahe tradition}

Mushingantahe (or Bashingantahe in plural) is Kirundi for "a man of integrity." Every adult, married man who applies for the status of Bashingantahe goes through a symbolic process of initiation and is ceremonially recognized by the members in his village. Traditionally, Bashingantahe possess moral authority granted by their local community. With this comes a mandate to play mediation roles in their society. The institution of

\footnotetext{
${ }^{1}$ All the information in this section has been adapted from UPEACE AFRICA PROGRAMME, 2013
} 
Bashingantahe has a long history in Burundi society and served a double function. First, it promoted moral values among the community members, and, it was an accepted institution for dispute settlement in their society.

The tradition of Bashingantahe offers many opportunities for conflict transformation in Burundi society. Bashingantahe are involved in the settlement of land and other communal conflicts at the grass root level. In some localities, courts of law require the opinions and views of the Bashingantahe prior to settlement of the case. In the socio-political thinking of Burundians, the Institution of Bashingantahe symbolizes a kind of national pride and integrity. This makes it a potential structure of progressive rehabilitation of human values and moral authority. In a divided society like Burundi, this may constitute a powerful foundation for building societal harmony and peace.

2.6 Traditional conflict resolution in the Democratic Republic of Congo: Baraza Ya Wazee Baraza Ya Wazee is Swahili for "the forum for the elders." Due to cultural diversity in the Democratic Republic of Congo (DRC), it is impossible to have a home grown solution originating from one tradition which applies to the whole country. In 1998, more than five African armies and three rebel movements were fighting in the DRC. The province of North Kivu was rife with ethnic tensions. Under the leadership of then Governor Kanyamuhanga, two community initiatives were established to address the issue of inter-ethnic tensions and insecurity: the Provincial Commission of Pacification and the Baraza Inter-community forum for dialogue in North Kivu.

The Baraza members represent the various ethnic groups originating from North Kivu province: Nande, Hunde, Nyanga, Kumu, Kano/Rega, Tembo and the Banyarwanda who are broadly categorized in three social categories as Hutu, Tutsi and Twa. Each of the nine communities is represented by three people who are selected by their own community members to serve on the Baraza forum. In 2006, the Forum changed its name from Baraza Inter-community to Baraza Ya Wazee and subsequently opened its doors to participation of people who are not originally from North Kivu but are now residents (such as the people from Katanga and Kasai now living in Goma town).

The purpose of Baraza is to engage communities in frank dialogue in order to mitigate conflicts and create an environment that is more conducive for improving social cohesion and creating communal peace in the province. Baraza is also used as a tool for conflict prevention and mitigation. When conflicts arise in a community they are often exacerbated by tensions or rumors that undermine peaceful coexistence. In the Baraza approach, elders meet and discuss problems in order to help reduce such tensions. Baraza Ya Wazee has been involved in addressing the conflict between the Army Forces of the DRC and the National Council for the Defense of the People forces led by the dissident general Laurent Nkunda. Although the role of this instrument is primarily symbolic, it remains a commendable strategy which possesses unique potential to ease ethnic tensions in North Kivu in the post-electoral period in the DRC.

\section{Challenges to traditional methods of conflict resolution in Africa}

According to Mutisi (2011), despite their utility, certain challenges may prevent the complete application of traditional institutions of conflict resolution in African societies. Traditional African institutions have limitations that necessitate reforms, particularly in their convergence with modern political systems and their involvement of various actors on the socio-political stage. One challenge is that in some instances, traditional institutions are politicised and instrumentalised by elites for a variety of reasons. Too much state involvement in the determination of the jurisdiction, mandate and conduct of the traditional conflict resolution methods dilutes the institutions' independence, posing the danger of state-centrism in local initiatives (Mutisi, 2011).

In some cases, the apparently traditional institutions have become so diluted and translated into the language of the state that they have changed their character to become retributive and litigated in approach. Traditional methods of conflict resolution are not as purely restorative as they are often portrayed. The abunzi system demonstrates a level of ambivalence when it comes to the pursuance of restorative and retributive approaches to justice. In Rwanda, even though the abunzi institution pre-dates colonialism, its current form and approach to justice is modelled along the Alternative Dispute Resolution (ADR) jurisprudence (Mutisi, 2011). Such legalised mediation is not unique to Rwanda, for other countries, including the United States of America, also practise ADR.

Lastly, traditional institutions may not be able to handle every type of violent conflict on the African continent because 'their applicability is confined to specific conditions.' (Mutisi, 2011). When they were conceived during the pre-colonial era, they were usually designed to resolve small-scale familial, clan or community disputes, such as boundary disputes, land conflicts and petty theft. However, contemporary conflicts in Africa are often fought between disparate groups separated by language, religion, geography and political ideology. The place of traditional mechanisms in such instances can be limited in this respect. Furthermore, in the abunzi case, it would be imprudent to have a community-driven mediation process handling sensitive cases, such as sexual violence and other heinous crimes (Boege, 2006). 


\section{Conclusion}

In this paper we have shown that African traditional conflict management strategies offer paths to reconciliation but also face many challenges. The sources of these problems include the complexity of current conflicts among many others. Despite their limitations, these traditional conflict management instruments offer windows of opportunity to African communities in the areas of conflict prevention, challenging impunity, communal reconciliation and peace building. These local instruments have played a significant role in preventing the escalation of violence, in reducing fear and mistrust and in increasing dialogue in many communities in Africa. They have effectively and comprehensively complimented international responses for peace. In the case of Rwanda, they have even contributed to the restoration of hope where international interventions have failed. Because they are participatory methods, they also increase people's ownership of the conflict management process and form a favourable environment for collective social therapy. They are confidence building mechanisms and offer a potential structure for human values' rehabilitation and promotion in situations where a crisis of moral values has been both a cause and a consequence of inextricable violent conflicts. They constitute constructive tools for communal dialogue, tolerance and community mobilization, which are crucial in the search for restorative justice, reconciliation and sustainable development.

\section{References}

Aiyede, E.R. (2006). Theories in conflict management: PCR 701. Lagos. National Open University of Nigeria.

Anastase, S. (2015). Home grown mechanisms of conflict resolution in Africa's Great Lakes Region. Kigali. Centre for Conflict Management.

Ayindo, B. and Jenner, J. (2008). Training of trainers manual: Conflict transformation and peace building in $R$ wanda. USAID: Rwanda.

Boege, V. (2006). Traditional approaches to conflict transformation: potentials and limits. Berghof. Centre for Constructive Conflict Management.

Jabs, L.B. (2014). "No monkey destroys his forest:" A review of traditional African interpersonal conflict management. Journal of Global Peace and Conflict. 2(1). pp. 01-24.

Karbo, T. and Mutisi, M. (2008). 'Psychological aspects of post-conflict reconstruction: Transforming mindsets: The case of the gacaca in Rwanda'. Paper prepared for the ad hoc expert group meeting on lessons learned in post-conflict state capacity: Reconstructing governance and public administration capacities in postconflict societies Accra, Ghana October 2-4, 2008.

Masina, N. (2000). "Xhosa practices of ubuntu for South Africa", in W. I. Zartman (ed.) Traditional cures for modern conflicts: African conflict "medicine", Boulder, CO: Lynne Rienner Publishers.

Miller, C. E. (2005). A glossary of terms and concepts in peace and conflict studies. (second edition). Addis Ababa. University for Peace Africa Programme.

Musingafi, M.C.C., Dumbu, E., Mupa, P., Chiome, C., Chikukwa, H. (2011). Managing conflict in Africa. Processes, challenges and prospects. Saarbrucken: LAP Lambert Academic Publishers.

Mutisi, M. (2011). The abunzi mediation in Rwanda: Opportunities for engaging with traditional institutions of conflict resolution. Policy and Practice Brief. Durban. African Centre for the Constructive Resolution of Disputes (ACCORD).

National Unity and Reconciliation Commission. (2006). Training manual on conflict management. National Unity and Reconciliation Commission: Kigali, Rwanda

UPEACE AFRICA PROGRAMME. (2013). Peace education in Africa from a cultural perspective: Case studies from Kenya, Djibouti, Ethiopia and Somalia. New York. UNESCO. 